\title{
Novel field test design for acquisition of DC and AC parameters during service
}

Thorsteinsson, Sune; Poulsen, Peter Behrensdorff; Schou, Jørgen; Andersen, Anders Rand; Basu, Ronni; Sera, Dezso; Spataru, Sergiu; Oprea, Matei-lon

\section{Published in:}

Proceedings of IEEE 43rd Photovoltaic Specialist Conference 2016

Link to article, DOI:

10.1109/PVSC.2016.7749892

Publication date:

2016

Document Version

Publisher's PDF, also known as Version of record

Link back to DTU Orbit

Citation (APA):

Thorsteinsson, S., Poulsen, P. B., Schou, J., Andersen, A. R., Basu, R., Sera, D., Spataru, S., \& Oprea, M-I. (2016). Novel field test design for acquisition of $D C$ and $A C$ parameters during service. In Proceedings of IEEE 43rd Photovoltaic Specialist Conference 2016 (pp. 1608-1610). IEEE.

https://doi.org/10.1109/PVSC.2016.7749892

\section{General rights}

Copyright and moral rights for the publications made accessible in the public portal are retained by the authors and/or other copyright owners and it is a condition of accessing publications that users recognise and abide by the legal requirements associated with these rights.

- Users may download and print one copy of any publication from the public portal for the purpose of private study or research.

- You may not further distribute the material or use it for any profit-making activity or commercial gain

- You may freely distribute the URL identifying the publication in the public portal 


\title{
Novel field test design for acquisition of DC and AC parameters during service
}

\author{
Sune Thorsteinsson ${ }^{\mathrm{a}}$, Peter Behrensdorff Poulsen ${ }^{\mathrm{a}}$, Jørgen Schou ${ }^{\mathrm{a}}$, Anders Rand Andersen ${ }^{\mathrm{b}}$, Ronni Basu ${ }^{\mathrm{b}}$, \\ Dezso Sera ${ }^{c}$, Sergiu Spataru ${ }^{c}$, Matei-Ion Oprea ${ }^{c}$ \\ ${ }^{a}$ Department of Photonics Engineering, Technical University of Denmark, Frederiksborgvej 399, Building \\ 130, 4000 Roskilde, Denmark, *sunth@fotonik.dtu.dk, phone: +45 46774521 \\ ${ }^{\mathrm{b}}$ Emazys Technologies Aps, Lysholdt Allé 6, 7100 Vejle, Denmark \\ ${ }^{\mathrm{c}}$ Aalborg University, Department of Energy Technology, Pontoppidanstraede 101, 9220 Aalborg, Denmark
}

\begin{abstract}
Being able to monitor early signs of PV module degradation, is needed to ensure stable power production throughout the service life of a PV installation. Recently, impedance spectroscopy is proven to be a useful tool for detection of the presence and location of significant errors, and may have potential for more. In this work we describe a field test design where the modules are operating at their maximum power point, and via relays is switched out one by one for acquisition of an IV curve and an impedance spectrum. Some of the modules involved will undergo stimuli to accelerate certain degradation mechanisms, and fitting parameters extracted from the field test will be correlated with irradiance and compared to similar parameters of virgin modules of same kind, and conventional laboratory measurements on the same modules. The proposed method will provide data for exploration of early degradation signs using impedance measurements.
\end{abstract}

\section{INTRODUCTION}

Despite manufacture guarantee of 25 years, many defect and failure mechanisms occur on PV-modules in the field [1], [2]. For most non-solar farm installations the performance ratio is not monitored carefully [3]. Thus defects and failures are not discovered until they have developed significantly, a significant visual defect occurs or the power production from the installation decreases 10's of \% from one year to another. For residential installations, inspections and error searching are also associated with significant costs, almost comparable to the value of the installation.

Time domain reflectometry has been proposed and proved to be able to locate faults on a single PV string [4]. Recently, a new method has become commercially available for detecting the location of significant faults as open circuits, shorts, failing bypass diodes and earth faults [5]. This technique is based on advanced analysis of impedance measurements. Impedance spectroscopy has been widely used for DSC cells (Dye Sensitized Solar Cells) and thin-film technologies for decades. However, recent research shows promising results also applied on PV modules. This work will describe a measurement setup and preliminary results for a further investigation of which information about the PV modules health can be extracted from impedance analysis.

\section{THEORY}

Interpretation of impedance spectra's using $\mathrm{AC}$ equivalent circuits for one specific spectra is fairly well described in the literature [6]-[8] and from [8] the simplified equivalent circuit model shown in Fig. 1. is found.

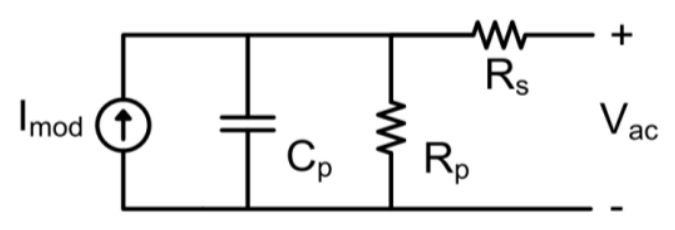

Fig. 1. Simplified equivalent AC circuit model of a PV-module

In the model the corresponding complex impedance is given by $Z_{\mathrm{PV}}$

$$
Z_{P V}=\left[R_{S}+\frac{R_{P}}{\left(\omega R_{P} C_{P}\right)^{2}+1}\right]-j\left[\frac{\omega R_{P}^{2} C_{P}}{\left(\omega R_{P} C_{P}\right)^{2}+1}\right]
$$

which can be fitted to measured data, and from there values of for $R_{s}, R_{p}$ and $C_{p}$ can be found. However, it is well known from the literature that these parameters change with illumination, and the bias.[6], [7], [9].

\section{FIELD TEST}

The overall objective of this work is to establish a field test that enables to investigate how the faults on PV modules develop during normal operation. Of particular interest is to monitor and compare the impedance spectra recorded in the open circuit bias with the IV-curves. The recorded panel data will then be correlated with irradiance data and module temperature data.

The objective described above will be achieved by connecting the modules to commercially available load electronics for grid connection. A relay system will be created which can switch the modules into a "measurement bus" facilitating a measurement of an IV-curve and acquisition of an impedance spectrum. The modules mounted on the field test will all be of the same kind and batch from the producer. 
However, some will be new, and some will have been exposed to accelerated aging to stimulate specific degradation mechanisms.

The overall principle is shown in Fig. 2. and the load system is designed with the aim to maximize the time each module is operating in its maximum power point.

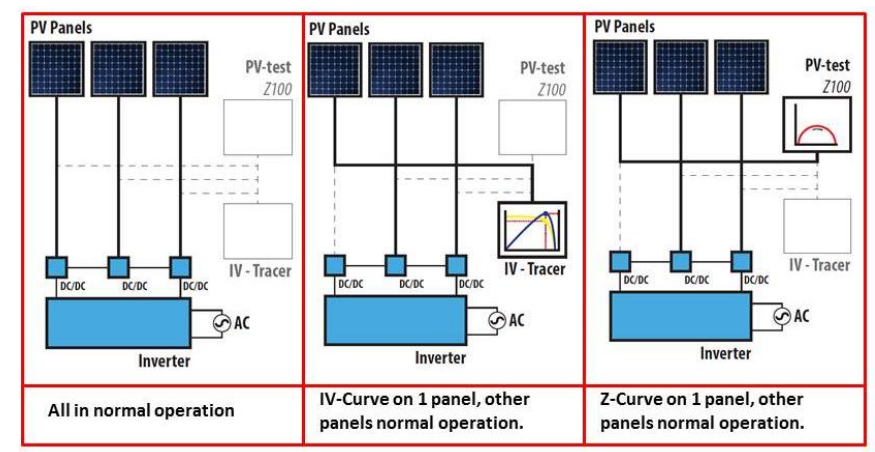

Fig. 2. Conceptual sketch of the field test.

SolarEdge power optimizers (OP 250-LV) will be connected to the modules, allowing independent module operation for module voltages above 5 volts. The output of the power optimizers is connected in series to a Solar Edge 3 KVA inverter. The serial architecture of the power optimizer system allows tracking at low voltages, which increases the module choice, to better match physical limitations of e.g. chambers for accelerated ageing. However, a minimum number of panels are required to insure sufficient input voltage to the inverter. The first type of PV modules to be mounted on the testing rack are multi crystalline panels with 36 cells. The modules have a peak power of $150 \mathrm{~W}$, and a maximum power point voltage of 18 Volts. In the field test, 18 panels of these will be mounted resulting in $2.55 \mathrm{kWp}$ since one module will always be switched out for measurements and thus the inverter is oversized to avoid power limitations of the inverter.

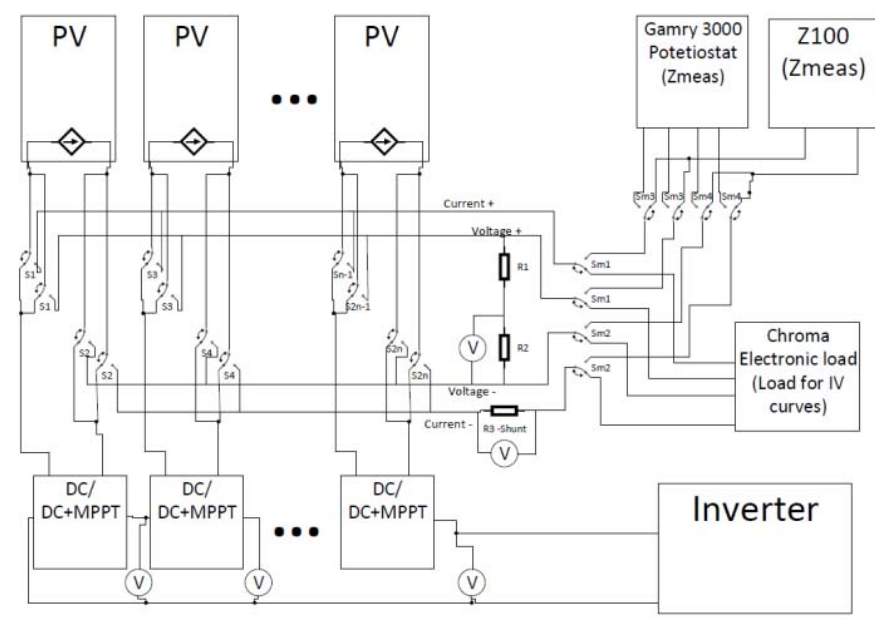

Fig 3. Wiring concept of the field test
The wiring diagram is shown in Fig. 3, it consists of a module part switching the individual modules in to a measurement bus, consisting of both sense and current wires, and a measurement part directing the other end of the measurement bus to the desired characterization equipment.

The relays and measurement system is controlled via LabVIEW using the FPGA based Compact Rio technology where fast data acquisition is possible, and safety checks in the measurement routines allows only one panel at a time to be switched to the measurement bus.

Out of the 18 panels, 8 will be characterized in a cyclic routine with IV-curves and impedance spectra. 17 modules give a total nominal DC voltage on the module side of $306 \mathrm{~V}$. This is chosen in order to give power optimizers a relatively low boost ratio of approximately $15 \%$, and thereby maximizing their operating range.

For the IV-tracing an electronic load will load the module to obtain 1. quadrant IV curves, with the voltages and current being measured by an external data logger capable of simultaneous sampling with a rate of $50 \mathrm{ks} / \mathrm{sec}$. For impedance measurement a Z100 device from EmaZys Technologies Aps and a Gamry 3000 AE potentiostat will be used. The impedance of the cables will be measured with the cable shorted and used to correct the impedance measurements on the modules. An outdoor reference cell and a pyranometer will be mounted in plane of array (POA), with the first being able to detect fast changes in radiation and the latter being able to measure the POA irradiation precisely. The fast response time of the reference cell combined with the fast logging using the FPGA allows for point irradiance corrections of the IV curves. The temperature on the back of each module will also be logged using thermocouples.

\section{EXPERIMENTAL PLAN}

The aim of the field test is to search for signs of early degradation of modules, of particular interest is:

- By pass diode failures

- $\quad$ Potential induced degradation (PID)

- Micro cracks

- Ribbon damage

- Delamination

To obtain the best possible starting point 32 modules, fabricated in the same batch, will be used for the investigation.

- 2 modules will be flashed and stored in darkness to be used as reference

- 5 modules will be mounted outside and used as outdoor reference to monitor natural degradation

- 10 modules will be exposed to mechanical loads introducing micro cracks

- 5 modules will be exposed to high voltage to stimulate PID degradation

- 10 modules will be reserved for thermal aging 
Prior to any stimuli, flash curves, impedance spectra and electroluminescence (EL) test are performed on the modules. The outdoor reference modules together with a selection of modules that has received degradation stimuli will be mounted on the field. Prior to mounting on the field test, flash tests, ELtest and laboratory impedance spectra's will be record as references.

The fitted values for the AC parameters being the parallel resistance, the series resistance and the parallel capacitance will be correlated with irradiation and temperature, and their development will be monitored and compared with flashing results and EL imaging. It is the expectation from the authors, that these experiments will guide the way for using impedance spectroscopy on installations to detect early signs of module degradation.

\section{SUMMARY}

In this work we have described a field test design with the purpose of getting more knowledge of PV module degradation by investigation by impedance spectroscopy alongside IV characterization. The modules are operating at their maximum power point, and are switched out one by one via relays for acquisition of an IV curve and an impedance spectrum. Some of the modules involved will undergo stimuli to accelerate certain degradation mechanisms, and fitting parameters extracted from the field test will be correlated with irradiance and compared to similar parameters of virgin modules of same kind, and conventional laboratory measurements on the same modules. The proposed method will provide data for exploration of early degradation signs using impedance measurements. The field test is in the moment in its final state of preparation and the software is close to being finished enabling a commissioning during the summer of 2016.

\section{ACKNOWLEDGEMENT}

This research is funded by the Danish Energy Agency within the EUDP programme with the project journal number 64014-0507 "New technology for localization and characterization of faults in solar panels".

\section{REFERENCES}

[1] M. Köntges, S. Kurtz, C. Packard, U. Jahn, K. A. Berger, K. Kato, T. Friesen, H. Lui, and M. Van Iseghem, "Review of Failures of Photovoltaic Modules," 2014.

[2] D. Degraaff, R. Lacerda, and Z. Campeau, "Degradation Mechanisms in Si Module Technologies Observed in the Field; Their Analysis and Statistics," PV Modul. Reliab. Work. Golden, CO, no. February, 2011.

[3] J. Leloux, J. Taylor, R. Moretón, L. Narvarte, D. Trebosc, A. Desportes, and S. Solar, "Monitoring 30,000 PV systems in Europe: Performance , Faults , and State of the Art," no. September, 2015.

[4] T. Takashima, J. Yamaguchi, and M. Ishida, "Fault detection by signal response in PV module strings," Conf. Rec. IEEE Photovolt. Spec. Conf., no. 1, pp. 8-12, 2008.

[5] Emazys, "Z 100 PV analyzer.” Emazys, 2015.

[6] D. Chenvidhya, K. Kirtikara, and C. Jivacate, "PV module dynamic impedance and its voltage and frequency dependencies," Sol. Energy Mater. Sol. Cells, vol. 86, pp. 243251,2005

[7] M. P. Deshmukh, R. A. Kumar, and J. Nagaraju, "Measurement of solar cell ac parameters using the time domain technique," Rev. Sci. Instrum., vol. 75, no. 2004, pp. 2732-2735, 2004.

[8] J. Johnson, D. Schoenwald, S. Kuszmaul, J. Strauch, and W. Bower, "Creating dynamic equivalent PV circuit models with impedance spectroscopy for arc fault modeling," 2011 37th IEEE Photovolt. Spec. Conf., pp. 002328-002333, 2011.

[9] T. Pongklang, D. Chenvidhya, and K. Kirtikara, "Voltage and frequency dependent impedances of dye-sensitized solar cell," Energy Procedia, vol. 52, pp. 536-540, 2014. 